Marta POLACZEK-BIGAJ

Uniwersytet Jagielloński

martoska@interia.pl

\title{
THE INFLUENCE OF THE EXISTENCE OF
}

AND THE PROCESS OF THE LIQUIDATION OF

THE WORKERS' PUBLISHING COOPERATIVE

"PRESS - BOOK - RUCH"

ON CONTEMPORARY PRESS SYSTEM

ABSTRACT The article points out the problems of the influence of the political transformation in Poland on creating the contemporary press market. It explains the historical importance of the Workers' Publishing Cooperative "Press - Book - Ruch" (WPC) in the period of the People's Republic of Poland, which was the biggest press concern across Central and Eastern Europe and was an extremely important element of the political system which had been under the full influence of the Polish United Workers' Party. It owned most of the press titles on Polish market, so when in 1990 the liquidation of the Collective was started, there were many significant problems of political, financial and social nature. Moreover, in the process of purchasing Polish newspapers and magazines was joined not only by domestic forces but also foreign capital and international investors, which made this privatisation even more difficult and controversial. Main problems were mentioned as well as examples of incompetence of Liquidation Committee or loopholes which caused serious difficulties.

Keywords: media, press market, transformation, Workers' Publishing Cooperative "Press - Book - Ruch", foreign capital 


\section{INTRODUCTION}

The People's Republic of Poland as ruled by the communist authorities was characterised by the monopoly of power, a centrally-controlled inefficient economy and the dominant role of Polish United Workers' Party. Also the state of mind of the society was worsening because the state could not satisfy the basic consumer aspirations of its citizens. As a result, this increased dissatisfaction caused by living in a nondemocratic system led to numerous strikes and public protests. Also, the media system did not work properly during this period. Its significant problems were the lack of freedom of speech, a totally controlled publishing market and all-pervasive censorship.

In 1980s the situation was serious enough to show a necessity to improve the economic situation in the country and make a decision about initiating negotiations with representatives of the opposition - including "Solidarnośc", democratic organisations and trade union representatives. Nevertheless, the authorities were firm about the assumed weakness of anti-communist opposition. One of the best examples of underestimating the opponent was the public debate between Lech Wałęsa and Alfred Miodowicz presented on TV on $30^{\text {th }}$ November 1988. Before the meeting no one had thought that it would turn out to be a triumph of the "Solidarność" leader - it had been expected to be a casual discussion showing how magnanimous the authorities were to agree to this very debate. The result exceeded even the expectations of the opposition. It was an undisputed success for Wałęsa who was for the first time shown on TV, which authenticated his position as a leader and moreover his statements were much more accurate.

This debate could be called the visible sign of forthcoming changes. A turning point came in 1989 during the Round Table meetings between $6^{\text {th }}$ February and $5^{\text {th }}$ April. The agreements signed as a result of these negotiations assumed the reforming political and economic system of the People's Republic of Poland and carrying out these reforms in an evolutionary way. The new system was to be based on political pluralism, the freedom of speech, integrity of the judiciary, strong local government, free market development and economic competitiveness. Furthermore, the foundation of the Senate and restoration of the presidency were declared. However, despite the fact that Senate elections were declared to be free, the Sejm elections had a contract character - the proportions of seats decided in advance, giving $65 \%$ of seats in the new Sejm to the then-government and $35 \%$ to the opposition.

These general state changes raised the possibility of creating a new system of mass media to the then existing model. Modifications within the media of mass communication which were a natural preservation of transforming political systems from socialist model to a democratic one took place in the entire Central and Eastern Europe. They included quantity and quality transformations on the media market - in all mass media and all areas of journalism. ${ }^{1}$

J. Jarowiecki, Przeksztatcenia prasy polskiej w latach 1989-1995, in A. Słomkowska (ed.), Transformacja mediów 1989-1995, Warszawa 1996, p. 43, Materiaty Pomocnicze do Najnowszej Historii Dziennikar- 
During the agreements there were narrowly specialized working teams and the Panel of the Mass Media of the Round Table was responsible for the issue of mass communication. Its works concentrated on the liquidation of Radiokomitet, which totally controlled the media structures, moreover, the problem of sharing TV programmes between authorities and opposition powers was discussed. ${ }^{2}$ Finally there were two more extremely important aspects of this Panel's works. Firstly, the need for abandoning the licensing system and replacing it with a reporting or registration system. Secondly, solving all the problems connected with the existence and inevitability of the liquidation of the Workers' Publishing Cooperative meant changes in the rationing of paper, multiplying publishing companies and giving press titles to other subjects.

Signing the agreements of the Round Table started the process of rapid destruction of the former political system and, through overthrowing the dictatorship of the Polish United Workers' Party, the process of establishing democracy began. All the changes included building the contemporary press system on which the main influence was the liquidation of the Workers' Publishing Cooperative and the introduction of the system of press registration instead of the license system.

\section{WORKERS' PUBLISHING COOPERATIVE - THE FOUNDATION OF THE MEDIA SYSTEM IN THE PEOPLE'S REPUBLIC OF POLAND}

Witold Bereś writes that free press came with free Poland ${ }^{3}$ which is undoubtedly true. Democratisation of the state system led to creating a new media market. Among the most important acts of law were the Relation between the Country and the Catholic Church Act in the People's Republic of Poland ${ }^{4}$, the Guarantees of Freedom of Consequence and Religion Act $\left(17^{\text {th }} \text { May 1989) }\right)^{5}$, the act Amending the Press Law Act $\left(30^{\text {th }} \text { May 1989 }\right)^{6}$ or Change of the Constitution of the People's Republic of Poland Act $\left(29^{\text {th }}\right.$ December 1989). ${ }^{7}$ However, the meaningful culmination of these changes came

stwa, Vol. 26; translation after: M. Kaczmarczyk, The mass media in Poland. Between the Mission and the Market, Trnava 2012, p. 50.

2 This was an interesting issue. The authorities were possibly ready to share TV programmes with church representatives but they absolutely did not want to allow any other groups to use this medium. The church was seen as hierarchical and well-organised, which made it more predictable and easier to control. As a result of negotiations the solution was developed to give Programme 1 and 2 to the authorities, the $3^{\text {rd }}$ Programme to opposition powers.

3 W. Bereś, Czwarta wtadza. Najważniejsze wydarzenia medialne III RP, Warszawa 2000, p. 22.

4 Ustawa z dnia 17 maja 1989 r. o stosunku Państwa do Kościota Katolickiego w Polskiej Rzeczypospolitej Ludowej, Dz. U. 1989, nr 29, poz. 154.

5 Ustawa z dnia 17 maja 1989 r. o gwarancjach wolności sumienia i wyznania, Dz. U. 1989, nr 29, poz. 155 .

6 Ustawa z dnia 30 maja 1989 r. o zmianie ustawy - Prawo prasowe, Dz. U. 1989, nr 34, poz. 187.

Ustawa z dnia 29 grudnia 1989 r. o zmianie Konstytucji Polskiej Rzeczypospolitej Ludowej, Dz. U. 1989, nr 75 , poz. 444 . 
with the act repealing the Publications and Performances Control Act abolishing the bodies of this control and the Change of Press Law Act passed by the Sejm on $11^{\text {th }}$ April $1990^{8}$ which gave the real and full freedom of mass media in Poland. All these acts have created the basis of the contemporary media system. The last document that should be mentioned (and which chronologically corrects omitting the change of Press Law) is the Act concerning the liquidation of the Workers' Publishing Cooperative from $19^{\text {th }}$ March 1990. ${ }^{9}$ This is the date when building the new press market in Poland began. To understand the importance of these complicated process of liquidation, it is necessary to explain the historical meaning of the Workers' Publishing Cooperative (WPC) in the period of People's Republic.

This institution was an extremely important element of the political system which had been under the full influence of the Polish United Workers' Party. The Cooperative was founded on the $1^{\text {st }}$ January 1973 on the initiative of the Communist Party, through a combination of WPC "Press", "Book and Knowledge" Publishing House and the Enterprise for Dissemination of Press and Books "Ruch". WPC was the biggest press conglomerate across Central and Eastern Europe. In addition to publishing most high-volume publishing newspapers and magazines, it also dealt with the issuing of postcards, greeting cards, calendars, CDs, music cassettes and audio-visuals. This important role was supplemented by other indirectly incorporated press institutions this huge Cooperative also contained the Polish Interpress Agency, the Central Photographical Agency, the Youth Publishing Agency and the National Publishing Agency.

The number of institutions that WPC included shows its significant impact on the political life, particularly the strengthening the position of Polish United Workers' Party. Notwithstanding, the Cooperative also had an additional role and purpose - it brought huge financial profits. For the Communist Party, the dividend, usually paid in monthly installments constituted one of the three main sources of income and was ranked just next to the direct budgetary grants and membership fees, while their amount was established by the Central Committee of the Communist Party during planning of the party's budget.

As it was shown, the Cooperative was in the possession of the printing networks, paper mills, agencies, press clubs, distribution companies, kiosks and employees' holiday homes or plots. At the end of the 1980's, the Cooperative employed about ninety thousand people, published about 90 per cent of daily press editions ${ }^{10}$ and about 70 per cent of all magazine editions. ${ }^{11}$ Andrzej Grajewski rightly observes that the existence of WPC

Ustawy z dnia 11 kwietnia 1990 r. o uchyleniu ustawy o kontroli publikacji i widowisk, zniesieniu organów tej kontroli oraz zmianie ustawy - Prawo Prasowe, Dz. U. 1990, nr 29, poz. 173.

9 Ustawa z dnia 22 marca 1990 r. o likwidacji Robotniczej Spótdzielni Wydawniczej „Prasa-Książa-Ruch", Dz. U. 1990, nr 21, poz. 125.

10 The only daily press titles not published by the Cooperative were: "Słowo Powszechne", "Kurier Polski”, "Rzeczpospolita”, “Żołnierz Wolności” - see A. Grajewski, 'Bitwa o prasę. Krótki zarys likwidacji koncernu prasowego RSW', Więź, No. 11 (1992), p. 43.

11 K. Schliep, 'Prywatyzacja prasy', in G.G. Kopper, J. Rudkiewicz, K. Schliep (eds.), Media i dziennikarstwo $w$ Polsce 1989-1995, Kraków 1996, pp. 129-130, translation after: M. Kaczmarczyk, The mass media... 
was one of the pillars of political parties, and in Polish conditions the adopted size and concentration of the press was led to an extent unknown even in other countries of real socialism. ${ }^{12}$

The company existed in an almost unchanged form till the end of the 1980s. It was a typical feature of the system maintained by mono-party authorities. However, the process of political changes endangered the Cooperative's position. Sławomir Tabkowski, the last president of WPC, when mentioning his relations with the Company ${ }^{13}$, says: So I was looking at WPC still unchanged, but requiring rapid and major transformation. After the departure of Gtowczyk, the time in which Mieczyslaw Rakowski supervised the department of propaganda was very short (from late June to early autumn 1988), however my next boss Stanislaw Ciosek was not at all interested in the affairs of the WPC and considered them of secondary importance (inter alia, the proof might be the fact that since autumn of 1988 - for almost a year, the Supervisory Board didn't meet even once). For more than three years there had been no changes in the offer of WPC's titles outside the much earlier liquidation of Radar (apparently for political and personal reasons). Coincidence and inertia caused that no changes in WPC were made. ${ }^{14}$ As Tabkowski said, the leadership seemed to be oblivious to the need for change, or blindly believed that nothing could threaten the company's current position. Even when in the summer of 1989 there was a press campaign against WPC, President Wiesław Rydygier was saying that nothing could change.

A frequent opinion which may be found in literature says that a condition necessary to make the media democratic was to stop the monopoly. ${ }^{15}$ That was one of the basic postulates of the Solidarność movement, and the Round Table finally gave the impulse to undertake these changes.

\section{LEGAL BASIS AND THE LIQUIDATION PROCESS.}

Formally the process of liquidation was started much later than the Round Table negotiations. Nothing happened until $19^{\text {th }}$ March 1990, when the Prime Minister Tadeusz Mazowiecki, directed the project of the bill of liquidation of the Workers' Publishing Cooperative "Press-Book-Ruch"16 to the Speaker of the Sejm, Mikołaj Kozakiewicz. The new government treated this case as a priority and its importance

\footnotetext{
A. Grajewski, 'Bitwa o prasę..., p. 43. Translated by the author.

13 On $11^{\text {th }}$ April 1989 S. Tabkowski came to WPC and was appointed as the President of the Board of the Supervisory Board.

14 Opinion of S. Tabkowski in his private note prepared on $14^{\text {th }}$ January 2011 for one of the interviews arranged by the author.

15 M. Kaczmarczyk, The mass media..., p. 54.

16 Paper of the Prime Minister Tadeusz Mazowiecki to Mikołaj Kozakiewicz including a project of the law accepted by the Council of Ministers on 19th March 1990, Projekt ustawy o likwidacji Robotniczej Spótdzielni Wydawniczej „Prasa-Książka-Ruch” wraz z uzasadnieniem, Druk nr 291, Warszawa, 19 March 1990.
} 
was seen in authorising the Minister - the Head of the Office of the Council of Ministers - to represent the position of the Government on this issue in the course of parliamentary work. This document not only proposed to change in the law but also attempted to give a wider explanation of circumstances that forced the government to take such a decision. The need for the liquidation of statutory regulations stemmed from the fact that in the process of work of the Commission of Government Affairs of Legal State Property of Political Parties and Youth Organizations with the participation of the Committee of Property of former Polish United Workers' Party and the Supreme Council of the Social Democracy of the Republic of Poland - the issue of succession rights of the Social Democracy of Poland after the Communist Party in relation to WPC "Press - Book - Ruch" - has not been resolved due to the lack of a constructive position of Polish Social Democracy. ${ }^{17}$

In addition, the Government was aware that throughout its more than 40-year existence, WPC was one of the key elements of the previous system and co-created structure of the political monopoly of one party. Because the society had no alternative sources of knowledge, using the Cooperative was an easy method of manipulating the media and a means of communication in order to influence society. Another complaint, mentioned in the document, was the use of state structures to expand the size of the Cooperative, and, from this position, the subsequent strengthening power of the only governing party.

Financial arguments were other important aspects. The government contested the legality of some elements included in the WPC. For example several companies and institutions were transferred to the Cooperative in the way omitting the law as an arbitrary administrative decision, taken at a high level of government. Not only the ownership of some entities raised objections but also the fact that RSW has benefited from huge tax exemptions. For example, the data from 1988 show that as a result of these cash incentives the Cooperative has saved 52 billion PLN as a consequence of not paying part of its taxes on income, marketing, sales, CDs and cassettes as well as payroll tax. As has already been mentioned, profits gained by WPC went to the treasury of the Communist Party - the governmental document also pointed to this aspect. Furthermore, it was calculated that the other shareholders of the Cooperative received only residual benefits of these revenues, which was about $5 \%$.

The remaining section of the document mentions the risks of pluralism which came from maintaining functionality of WPC. The Cooperative had significant shares in the domestic market - it owned almost the entire printing base and the majority of daily newspapers, major weeklies nationwide, weekly public information and press distribution, which meant that that pluralism could not be fully possible.

As a logical consequence of the disintegration of Polish United Workers' Party and its place being taken by Social Democracy of the Republic of Poland (SDRP), the new party got significant shares in the Cooperative (95\%). This situation could lead to placing this party in a privileged position compared to all other parties, unions and associations. On

17 Ibid. 
$18^{\text {th }}$ March 1990, they presented to the Government Commission a Declaration of Intent on the WPC "Press-Book-Ruch", which did not announce any radical qualitative changes. Therefore, if the Cooperative was kept in the hands of SDRP it would give this party a special position and any real market pluralisation could not be possible.

There were three different projects of deconstructing the WPC prepared by left-wing politicians - from very liberal through moderate to these most radical. It is obvious that at the beginning SDRP presented the least extreme proposals, however, those more radical ones were also known to the government and they assumed there would be no external liquidation unless it came with the introduction of full pluralism. Nevertheless, the government side did not refer to these proposals relying on the fact that their original propositions strongly proposed less radical demands. ${ }^{18}$ No further negotiations took place, because the government decided to deal with the matter in a dramatic way instead of taking any proposal to negotiations. Therefore, the last paragraph of the Explanatory Memorandum stated that Currently the law does not create sufficient opportunities to take of action reorganization and restructuring by factors external to $W P C$, especially revindication of the state property which earlier had been transferred free of charge to the ownership of the WPC. ${ }^{19}$

The project proposed by the Government was briefly established and its content was nearly unchanged relative to the original version. However, the problem occurred not in the lack of changes but in the speed of parliamentary works, which probably caused only quick acceptance of the governmental project. Michał Kaczmarczyk also draws attention to this brief kind of decision-making process and says In this situation, on $19^{\text {th }}$ March 1990, the first non-communist government of Tadeusz Mazowiecki adopted a draft law on WPC. Three days later, the Sejm passed the Act declared by the Council of Ministers, and on the 6th April 1990 the Prime Minister appointed the Liquidation Committee. ${ }^{20}$

This rush caused many imperfections and the liquidation process lasted for more than a decade. Despite the fact that its main aim was to give the basis under which a new plural press market could be created, many arbitrary decisions had been made and in the literature it is often found that the Committee had existed so long because it was in its own particular interests not to guarantee a better process of liquidation. Before presenting all these problems it is necessary to analyse specific articles of this Law.

According to this Bill, the process of liquidation started immediately when the act came into force and the Liquidation Committee was appointed. As Andrzej Grajewski says, in the evening on the $5^{\text {th }}$ April 1990 there was the first meeting of the Committiee's members who were: Jan Bijak ("Polityka", Editor in Chief), Andrzej Grajewski ("Gość Niedzielny", Editor), Alfred Klein (lawyer - researcher of University of Wroctaw), Kr-

18 This situation was logical because it was not in their interest at the very beginning to show all the cards and folding offers the least favorable for themselves.

19

Ibid.

20 M. Kaczmarczyk, Od kaszty do notebooka. Transformacja technologiczna organizacji prasowych w Polsce po 1989 roku, Sosnowiec 2013, p. 58, Komunikacja Spoteczna - Humanitas. 
zysztof Poklewski-Koziett (lawyer - "Pan'stwo i Prawo", member of the editorial office), Maciej Szumowski (member of Polish Journalists Association, "Gazeta Krakowska", editor in Chief 1980-1981), Donald Tusk (later leader of Liberal-Democratic Congress). Jerzy Drygalski ${ }^{21}$, researcher of University of $€$ ódz and associate of the newly created Ministry of Privatisation was chosen as the chairman of the Committee. During the meeting the Prime Minister explained that the main task of the Committee was doing the job pointed out in the law to let new political forces exist in the press market. No other deals were made. ${ }^{22}$

Everything started at once, which led to a bit of chaos. Eight people were needed to take over the structures of WPC, organize its management, deal with its difficult financial situation, create a liquidation scheme and cope with all the problems which concerned the Cooperative. It was definitely a huge job to do and to make the matters worse the methods of liquidation were not clearly explained and specified. The Bill gave three possibilities of transferring the property of press titles. The first option expected transfer of publications and other organizational units of the Cooperative with their dissociated parts for the cooperative work, which according to art. 5 were to be established by at least half of the employees of these units.

The rule of contribution in cash was introduced. This amount, however, was determined at the level of three times the average monthly salary received by the employees in these units in 1989. It was not an unreasonable requirement. Similarly, the requirements were assessed by Jan Majchrowski, who wrote that the conditions for such a transfer were rather symbolic and led to a contribution of membership shares by the members of the cooperative [...]. In the situation of couple hundreds' percentage inflation rate in the same year, one can talk about completely free allocation of some titles by the Liquidation Committee of the WPC. ${ }^{23}$

The second form of the taking over of the Cooperative's property was described in art. 6, which gave the possibility of organising an open tender. In this procedure only concerned those titles that had not been found attractive enough to be sold in the previous way. The highest price was the main sales criterion, however, also the most favourable conditions for the acquisition were analysed. In cases where the offer made by the cooperative was the same, it had a priority to purchase. Notwithstanding, the final decision was each time made by the liquidator which obviously aroused many controversies and led to the politicisation of the whole process. ${ }^{24}$

21 The committee members quickly changed. $16^{\text {th }}$ November 1990 the new chairman became Kazimierz Strzyczkowski, and in 1992 all the team was replaced. After the enactment no 66 of Prime Minister from $5^{\text {th }}$ March 1992, new chairman was called Leszek Jacek Hofman, and the enactment no 68 of Prime Minister from $8^{\text {th }}$ April Committee members were: Katarzyna Pietrzyk, Andrzej Smirnow, Eugeniusz Aleksandrowicz, Ryszard Czarnecki, Bartłomiej Kołodziej, Janusz Piechociński, Andrzej Rościszowski and Kazimierz Michał Ujazdowski.

22 A. Grajewski, 'Bitwa o prasę..., p. 44. Translated by the author.

23 J. Majchrowski, Ustawodawstwo Sejmu lat 1989-1991 a sprawa majątku bytej Polskiej Zjednoczonej Partii Robotniczej, Warszawa 2002, p. 112.

24 Compare: E. Ciborska, 'Transformacja prasy byłej PZPR', Zeszyty Prasoznawcze, No. 1-2 (1992). 
Art. 6 par. 3 introduced the last solution for those components of assets that had not been sold so far. As well as all profits from purchasing being transferred to the $\mathrm{Na}$ tional Treasury, any unsold titles and undistributed property could also have been nationalised. The intention of this article was to find a solution for the elements left after the first two options were used. However, the reality proved to be different and many abuses were noted while auditing the liquidation process.

As it was pointed out in the Information about the results of the inspection activities of the Liquidation Committee of the Workers' Publishing Cooperative: On the frailty of the Act, repeatedly observed in the implementation of its provisions, had impact (as it seems) woefully inadequate recognition of the scope and scale of the problems associated with the liquidation of such a large and complex structure. It should be emphasized that the framework and vague concepts in the Act constituted a need to refine the wording, but attempts in this regard aroused objections as to their legality. ${ }^{25}$

This report indicates many defects of the liquidation bill including a rushed legislation process or a divergence of interests and expectations. It was not easy to satisfy all political environments because all the political options wanted to gain for themselves as much as possible.

To sum up, in spite of the aforementioned difficulties most of the job was done in the first two years of the liquidation process which was shown by the inspection carried out by the Supreme Audit Institution. It indicated that in the first procedure of property transfer, 65 applications from workers' cooperatives were rejected. Mostly the rejections were motivated by financial reasons but the Committee also justified that it was too huge an asset to be transferred practically free of charge. However, 74 applications were approved and by April 1992, 71 of them were directed to cooperatives. Unfortunately, even if these numbers look impressive, much negligence was allowed which led to a low efficiency of all transformations. For example, in $1 / 4$ cooperatives the members did not fulfil the obligation of bringing the members' shares as well as the deadlines related to the submission of the required documentation were not respected. All these factors meant that many titles were not even able to start their activity like "Życie Literackie" ("Literary Life"). The audit report points out that Publishing Cooperative "New Literary Life," which under the agreement of $10 \mathrm{Oc}$ tober 1991 - free of charge - acquired all rights to the press title "Literary Life" (without the property editorial office) - till February 1992 did not take up any business. In addition, it was found that the Cooperative (registered in August 1990) also had no bank account, and its founding members in the number of 10 - due to lack of real opportunities to resume issuing the title - did not submit the required and declared members' shares at all. ${ }^{26}$

25 Informacja o wynikach kontroli dziatalności Komisji Likwidacyjnej Robotniczej Spótdzielni Wydawniczej „Prasa-Ksiazka-Ruch" - Information about the results of the inspection activities of the Liquidation Committee of the Workers' Publishing Cooperative, prepared by the President of Education, Science and Culture Team - Stefan Lubiszewski and accepted by the president of the Supreme Audit Institution Lech Kaczyński, Warszawa, 29 July 1992, p. 9.

Ibid., p. 16. 
Problems also appeared during the second procedure - the open tenders. On $20^{\text {th }}$ January 1990, Act of Changes to the Organization and Activities of the Cooperativeness ${ }^{27}$ was passed, where art. 4 established that the priority of purchasing would go to the person who offers the most favourable price and other conditions of transfer. No one explained what other conditions could have meant and this wording made this law very unspecific and it became a loophole. In each situation the final decision belonged to the Liquidation Committee, which could interpret it in any way. The audit report suggested that the proceeds from the sale of these tenders would have been bigher by 72 billion zt if the sole criterion for the selection of tenders were based only on the highest price. It should be added here that the Liquidation Committee sometimes resolved in favour of the tenders who do not yet have legal personality (eg. the case of the "Weekly Zamoyski"); some decisions aroused objections due to the continued economic consequences. ${ }^{28}$

Disclaimer aroused by the fact that the composition of the Liquidation Committee was addicted to political change, as it was the Council of Ministers that formed all its members. According to the controllers, the activities could be perceived as an opportunity to influence on the process of creating a new media market, whose independence should have been the main feature priority.

The workers' Publishing Cooperative was an important element strengthening the monopolistic communist system. Beginning its liquidation was a turning point, even a symbolic one, and started the formation of the new media market. Due to the wide range of units - from newspapers and printing to distribution - which were components of the WPC, the process of transformation gave the groundwork for the contemporary pluralistic media world. Despite the large number of the above misconducts that accompanied the entire liquidation, the changes that it brought helped to develop the newly established media market in Poland.

\section{BUILDING THE POST-LIQUIDATION PRESS MARKET}

Analysing the transformation of the media system, questions naturally appear - who took over the particular titles in the privatisation process and which political options gained the most? The answers are not easy and moreover contrary opinions appear in literature. ${ }^{29}$ Also during the Sejm debate in 1995 deputies estimated the liquidation process differently, but the vast majority judged it negatively. Statements appeared that

27 Ustawa z dnia 20 stycznia 1990 r. o zmianach w organizacji i dziatalności spótdzielczości, Dz. U. 1990, nr 6, poz. 36.

29 Compare: Sprawozdanie z likwidacji majątku bytej Polskiej Zjednoczonej Partii Robotniczej (The report on the liquidation of the assets of the former Polish United Workers' Party), Arnośt Becká, Jacek Molesta (issued by Home Office in 2001), they indicate a lack of evidence, difficulties in access to archival resources, small material collected by the liquidator, and the irreversible destruction of many documents. 
it was tearing a cloth $^{30}$ or a cash grab ${ }^{31}$. Tadeusz Samborski from Polish Folk Party (PSL) said that the structure and assets of the former WPC were torn like a cloth to deal for his friends and colleagues as generously as possible, not thinking at all about strategic matters like the Polish national interest, security, social and public media market releases. Then it was important to break down what existed and jerk for their friendly political forces as much as possible and not worry about the future. ${ }^{32}$ In general, negative opinions were the only common point, because when it came to naming the beneficiaries of this process each side felt as though it had lost. In the literature Jan Majchrowski claims that the whole procedure was played on the political key, which meant that right-wing parties had no luck in distribution and pluralisation of the press. ${ }^{33}$ Marek Siwiec had a different opinion that It was all, you might say, Wild West. Everyone bought what they wanted. At the time of the liquidation of the WPC, which was - let me emphasize it - much needed, it was some kind of a money grab. Press titles were simply taken by those who wanted to have them - well, maybe not by the one who wanted to, but the forces which then prevailed. A very significant part of titles were acquired by "Solidarnos'c" - using money borrowed from a huge French publishing house. ${ }^{34}$ To show the variety of points of view, it is worth mentioning that Konrad Napierała calls the whole process a dismemberment and fragmentation of the press market and influenced on this the policy of the government of the Liquidation Committee WPC Press-Book-Ruch, which was quite a particularistic concept of distribution of assets of the liquidated company between political factions that everyone got something there. In a sense, it was a rational action, but there was also a lot of naivety in it. ${ }^{35}$ Even if those opinions are often contradictory, they all contain some truth in themselves and the new press market started in a bit of mess.

As previously mentioned some titles were given to workers' cooperatives, others were sold at open tenders and the rest were taken over by the National Treasury. By these means hundreds of independent and self-controlled publications, which continued functioning on the free market and were determined by its factors, were created. This period is not easy to research, either, because in the newly opened market followed an instant reshuffle and shift of ownership from one entity to another. Michał Kaczmarczyk points out that the media began to compete with each other, the press market became varied and enriched with new titles. Although the number of cultural, literary and socio-political magazines was decreasing, at the same time there was a clear, quantitative growth of newspapers and magazines aimed at the mass audience. ${ }^{36}$ Another char-

\footnotetext{
30 It refered to the literary metaphor meaning the act of desperation.

31 Marek Siwiec's opinion registered on Transcript from the 43rd Sejm of second cadency meeting, day 3 , 17 Ferbuary 1995, at <www.sejm.gov.pl>.

32 Ibid.

33 J. Majchrowski, Ustawodawstwo Sejmu lat 1989-1991..., p. 113.

34 Marek Siwiec's opinion registered on Transcript form the 43rd Sejm of second cadency meeting, day 3, 17 February 1995.

35 Ibid.

36 M. Kaczmarczyk, Od kaszty do notebooka..., p. 59.
} 
acteristic change into this period was a dynamic development of women's press. Such magazines were extremely popular at the beginning of transformation. ${ }^{37}$ Titles well known in the times of the Peoples' Republic, like "Kobieta i Życie", "Przyjaciółka" or "Zwierciadło" 38 were still published but completely new publications also appeared mostly copied from well know foreign magazines. This was only one of the blooming press sectors on the new market besides a rapidly developing group of previously absent advertising, environmental or religious periodicals, as well as letters addressed to children, young people and various political groups. Publishing magazines on such subjects would not have been allowed before.

Building the post-liquidation press market was strongly influenced by one more factor besides political issues - the money aspect. Opening the new market was an attractive situation for foreign investors who with their capital successfully and without any limitations implemented their various initiatives both in the sector of newspapers and magazines. Poland was then seen as a very attractive market for foreign investors - thanks to extremely liberal policies of privatization of the Polish authorities, at a very low price one could buy a magazine with a high market value, with a long tradition, editorial facilities and established readership. ${ }^{39}$ Also the openness of the Polish market to everything western and the lack of regulations and institutions that would effectively control the evolution of the newspaper industry and the movement of capital was also conducive to the inflow of foreign capital. ${ }^{40}$

During the second tenure of the Sejm, in February 1995, a major debate on a topic related to the situation in the Polish press market was held, where the main problem of this sector was indicated by taking over a number of key (from the point of view of development of Polish public opinion) regional and national newspapers by external capital, understood as foreign capital. ${ }^{41}$ This situation resulted from the fact that full freedom of the circulation of shares and also as regards conducting any other owner-

37 Compare: T. Mielczarek, Monopol. Pluralizm. Koncentracja. Środki komunikowania masowego w Polsce w latach 1989-2006, Warsaw 2007, p. 171, Edukacja Medialna.

38 In 1989 in Poland 28 press titles addressed to women were published and 15 of them were published by WPC (others were controlled by different ministries and Polish Blind Association). After the transformation the following still survived on the market: "Przyjaciółka", "Pani", "Filipinka", "Uroda" and "Zwierciadło". The frequency of publishing of some of the magazines changed: "Filipinka" became a monthly magazine instead of a weekly or "Uroda" started to appear every month not every second month. 10 titles were closed. Compare: Z. Sokól, 'Kobiece czasopisma w Polsce w latach 1989-1991, in Ł. Szurmiński (ed.), Media a rok 1989. Obraz przemian i nowe zjawiska na rynku, Warszawa 2010, pp. 153, 167, Media Polskie, Vol. 8.

39 M. Kaczmarczyk, Od kaszty do notebooka..., p. 61.

40 O. Kurek, 'Współczesne media w Polsce', at <www.wsiz.rzeszow.pl>, 10 March 2013.

${ }^{41}$ Comapare: 16th point of the daily plan: Informacja prezesa Rady Ministrów w sprawie przejmowania szeregu kluczowych, z punktu widzenia ksztattowania polskiej opinii publicznej, tytutów prasowych tak regionalnych, jak i krajowych przez obcy kapitat (kapitat zagraniczny). (Information of the Prime Minister on a number of key acquisitions, from the point of view of development of Polish public opinion, newspapers as regional and national by external capital (foreign capital). Transcript form the 43rd Sejm (II term) meeting, day 3, 17 Ferbuary 1995. 
ship changes was allowed. The legislature did not set any limit on foreign capital involvement nor did it foresee the need for any security against the excessive participation of foreign investors. There also was not admitted to government agencies any legal title necessity to record and collect data showing the processes of privatisation. On entering the Polish market, publishing tycoons did not bear any obligation to notify the authorities of their plans and to report on their financial commitments. ${ }^{42}$ In direct contrast, this issue was solved in the radio and television sector, where the Broadcasting Act ${ }^{43}$ precisely regulated proportions of any kind of capital. The Council of Ministries presented the opinion that in the press publishing sector, like in other sectors of the economy, it is expected to attract foreign capital rather than neglect it. Native capital was not large and enterprising enough to take in this area full of initiative. As a consequence of this situation, representatives of well-known press companies, such as the French Hersant, British Maxwell or German Bauer appeared in Poland. This initiated purchasing by French company Socpresse group of Hersant significant shares of 8 major newspapers. Inter alia Hersant bought "Rzeczpospolita", shares in: "Dziennik Bałtycki" and "Wieczór Wybrzeża", in Łódź in "Express Ilustrowany" and "Dziennik Łódzki", in Kraków - in "Gazeta Krakowska" and sport magazine "Tempo", in Katowice in "Trybuna Śląska" and "Dziennik Zachodni". Another example of this expansive development by foreign investors could be "Życie Warszawy" in which minority shares were bought by Italian group Stei belonging to Nicola Grauso and their share soon increased to 95\% shares. Great interest in Polish press was also shown from the beginning by the Norwegian group Orkla Media, which for the needs of their investments in Poland created the company Orkla Press International and in 1995 controlled almost 10\% of the Polish press market and this proportion continued to increase. ${ }^{44}$

This situation raised the discussion about the pros and cons of foreign capital on the Polish press market. Opinions appeared that it would ruin domestic newspapers and magazines that Polish publishers would be eliminated from the market and that Polish press would not be Polish any more. Of course, the inflow of foreign capital also had positive effects which were noticed and commented upon by Henryk Dyrda, This capital when it comes to the press has been repeatedly needed. Needed were all - funding, experience and new ideas. The level of many, but certainly not all, newspapers raised very much. There are many new titles. ${ }^{45}$ Marek Siwiec remarked that The technical quality is completely different, the competition too which is also lowering prices in some sectors of the press, for example when it comes to women's magazines and family. ${ }^{46} \mathrm{But}$ it is hard not to admit that Tadeusz Samborski was correct, when he noted: It is clear that to a reasonable extent foreign capital should be allowed to market release, as well as it may fulfil a positive role, but controlling shares, especially in the case of leading opinion-

\footnotetext{
42 Ibid., Michał Strąk's statement.

43 Ustawa z 29 grudnia 1992 r. o radiofonii i telewizji, Dz. U. 1993, nr 7, poz. 34.

44 Orkla Media which overtaken "Rzeczpospolita" shares Hersant had withdrawn.

45 Transcript form the 43rd Sejm meeting...

46

Ibid.
} 
-making newspapers and magazines should be in Polish hands. ${ }^{47}$ Kazimierz Wilk feared that there threatens us that Poland will stay without Polish press, and that we will only exist Polish-language newspapers. ${ }^{48}$

\section{SUMMARY}

Deepening process of the strengthening of foreign capital in the newspaper market may incline to reflection on and expressing the opinions by many other people in recent years. Gunter Grass while visiting family in Gdansk said in surprise: I come to my hometown and see that Passauer Neue Press, using free-market conditions, found their place here, bought Polish newspapers. I warn against the consequences of this situation. This is outrageous and dangerous, when newspapers - instruments for shaping opinion, which should be the tribunes of free thought - pass into foreign hands. ${ }^{49}$

This opinion may seem emotional, so it is worth quoting other words - these of Mieczyslaw Albert Krąpiec: we are forced to bathe in the heavily polluted water of information which aims at changing the thinking of Poles, because no one spends money aimlessly. ${ }^{50}$ Contemporary research into the Polish newspaper and publishing industry stands, therefore, before the task of determining and showing these objectives to the public and moreover, the legislature and needs to build a system of legal protection for the public and national interest.

\section{BIBLIOGRAPHY}

Bereś W., Czwarta wtadza. Najważniejsze wydarzenia medialne III RP, Warszawa 2000.

Ciborska E., 'Transformacja prasy byłej PZPR', Zeszyty Prasoznawcze, No. 1-2 (1992).

Grajewski A., 'Bitwa o prasę. Krótki zarys likwidacji koncernu prasowego RSW', Więź, No. 11 (1992).

Jarowiecki J., 'Przekształcenia prasy polskiej w latach 1989-1995', in A. Słomkowska (ed.), Transformacja mediów 1989-1995, Warszawa 1996, Materiaty Pomocnicze do Najnowszej Historii Dziennikarstwa, Vol. 26.

Kaczmarczyk M., The mass media in Poland. Between the mission and the market, Trnava 2012.

Kaczmarczyk M., Od kaszty do notebooka. Transformacja technologiczna organizacji prasowych w Polsce po 1989 roku, Sosnowiec 2013, Komunikacja Spoteczna - Humanitas.

Krąpiec M., Spetniać dobro. Felietony z „Radia Maryja”, Lublin 2000.

Legutko P., Rodziewicz D., Mity czwartej wtadzy, Kraków 2002.

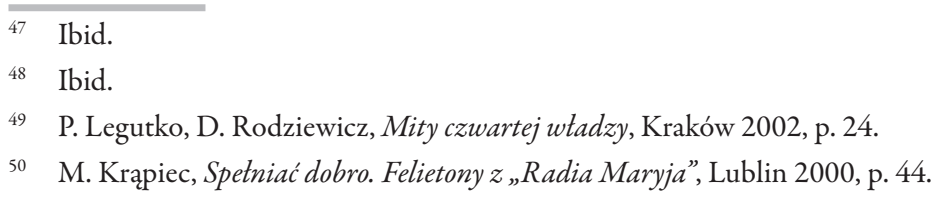


Mielczarek T., Monopol. Pluralizm. Koncentracja. Środki komunikowania masowego w Polsce w latach 1989-2006, Warszawa 2007, Edukacja Medialna.

Schliep K., 'Prywatyzacja prasy', in G.G. Kopper, J. Rudkiewicz, K. Schliep (eds.), Media i dziennikarstwo w Polsce 1989-1995, Kraków 1996.

\section{Acts of law}

Ustawa z dnia 17 maja 1989 r. o stosunku Państwa do Kościota Katolickiego w Polskiej Rzeczypospolitej Ludowej, Dz. U. 1989, nr 29, poz. 154.

Ustawa z dnia 17 maja 1989 r. o gwarancjach wolności sumienia i wyznania, Dz. U. 1989, nr 29, poz. 155.

Ustawa z dnia 30 maja 1989 r. o zmianie ustawy - Prawo prasowe, Dz. U. 1989, nr 34, poz. 187. Ustawa z dnia 29 grudnia 1989 r. o zmianie Konstytucji Polskiej Rzeczypospolitej Ludowej, Dz. U. 1989, nr 75, poz. 444 .

Ustawa z dnia 20 stycznia 1990 r. o zmianach w organizacji i dziatalności spótdzielczości, Dz. U. 1990, nr 6, poz. 36 .

Ustawa z dnia 22 marca 1990 r. o likwidacji Robotniczej Spótdzielni Wydawniczej „Prasa-Ksiązka-Ruch", Dz. U. 1990, nr 21, poz. 125.

Ustawy z dnia 11 kwietnia 1990 r. o uchyleniu ustawy o kontroli publikacji i widowisk, zniesieniu organów tej kontroli oraz zmianie ustawy - Prawo prasowe, Dz. U. 1990, nr 29, poz. 173.

Ustawa z 29 grudnia 1992 r. o radiofonii i telewizji, Dz. U. 1993, nr 7, poz. 34.

\section{Others}

Informacja o wynikach kontroli dziatalności Komisji Likwidacyjnej Robotniczej Spótdzielni Wydawniczej "Prasa-Ksiazka-Ruch” - Information about the results of the inspection activities of the Liquidation Committee of the Workers' Publishing Cooperative, prepared by the President of Education, Science and Culture Team - Stefan Lubiszewski and accepted by the president of the Supreme Audit Institution - Lech Kaczyński, Warszawa, 29 July 1992.

Informacja prezesa Rady Ministrów w sprawie przejmowania szeregu kluczowych, z punktu widzenia ksztattowania polskiej opinii publicznej, tytutów prasowych tak regionalnych, jak $i$ krajowych przez obcy kapitat (kapitat zagraniczny). (Information of the Prime Minister on a number of key acquisitions, from the point of view of development of Polish public opinion, newspapers as regional and national by external capital (foreign capital). Transcript form the 43rd Sejm of second cadency meeting, day 3, 17 Ferbuary 1995, at <www.sejm.gov.pl>.

Majchrowski J., Ustawodawstwo Sejmu lat 1989-1991 a sprawa majątku bytej Polskiej Zjednoczonej Partii Robotniczej, Warszawa 2002.

Kurek O., 'Współczesne media w Polsce', at <www.wsiz.rzeszow.pl>.

Paper of the Prime Minister Tadeusz Mazowiecki to Mikołaj Kozakiewicz including a project of law accepted by the Council of Ministers on 19th March 1990, Projekt ustawy o likwidacji Robotniczej Spótdzielni Wydawniczej „Prasa-Ksiązka-Ruch” wraz z uzasadnieniem, Druk nr 291, Warszawa, 19 March 1990.

Sprawozdanie z likwidacji majatku bytej Polskiej Zjednoczonej Partii Robotniczej (The report on the liquidation of the assets of the former Polish United Workers' Party), Arnośt Becká, Jacek Molesta (issued by Home Office in 2001). 
Tabkowski S., his private note prepared on $14^{\text {th }}$ January 2011 for one of the interviews arranged by the author.

Transcript from the 43rd Sejm of second cadency meeting, day 3, 17 Ferbuary 1995, at <www. sejm.gov.pl>.

Dr Marta POLACZEK-BIGAJ works in the Institute of Political Science and International Relations of the Jagiellonian University in Kraków. Her research focuses on legal and political aspects of the Polish media system. 